\title{
World Conference of Science Journalists: what are they for?
}

Conference

Reviewd by

Abstract

Keywords
WORLD CONFERENCE OF SCIENCE JOURNALISTS (WCSJ), SEOUL, KOREA, 8-12 JUNE 2015

\section{Javier Cruz-Mena}

The largest meeting of science journalists took place this summer in Seoul, Korea. It bore the imprint of a few of the previous ones - as a gathering to build community and encourage beginners -, but also showed some marked changes from when it all started back in 1992, as told by some of the leading actors.

\section{Science and media}

A young aspiring science reporter spoke a bit hurriedly during one of the most crowded, spirited and talked about sessions of the past World Conference of Science Journalists (WCSJ) from June $8^{\text {th }}$ to $12^{\text {th }}$, in Seoul, Korea. Just before the microphone was handed to her she was rather fidgety, perhaps battling a little stage fright. This was already the $9^{\text {th }}$ WCSJ, and by now it has become a very big event. She made a good point coherently, even if in overdrive, and looked quite proud once she was done. Having met her the previous day, I began pondering the question that drives this review: What is a WCSJ supposed to do for a young reporter like her?

I think the question is relevant because the WCSJ have undergone profound changes since they began in Tokyo, Japan, back in 1992. Arthur Bourne, President Emeritus of the European Union of Science Journalists Associations (EUSJA), described it as "one of the highlights of our professional lives". ${ }^{1}$ It must have been, indeed; but with 165 participants from 31 countries $^{2}$ it presents an interesting contrast with this summer's 1,000 journalists from 43 countries. The evolution, though, has been much deeper than just the size. According to Jean-Marc Fleury, Senior Advisor to the World Federation of Science Journalists (WFSJ), "the science journalists assembled in Tokyo declared that science journalism is a profession and that its further development through training and education programmes was necessary".

\footnotetext{
${ }^{1}$ http:/ /www.wfsj.org/files/file/news/2012/11/WFSJ10.pdf, p. 5.

${ }^{2}$ http:/ / www.wfsj.org/conferences/page.php?id=42.
} 
In this sense at least, Tokyo was nothing less than seminal. And that coming-of-age spirit certainly carried over to the $2^{\text {nd }}$ WCSJ, held in Budapest, in 1999 - the first meeting I attended. It still was a relatively small gathering, with most of us sharing meals, coffee breaks and constant conversation rather effortlessly. But transcendence was in the air. Prior to this year's trip to Seoul I contacted István Palugyai, organiser of the Budapest meeting, to put the WCSJ in historical perspective. He told me that Tokyo had left them with the feeling of a need to build professional contacts "to show good patterns and help in training". ${ }^{3}$ Hence, "the biggest benefit" of the $2^{\text {nd }}$ WCSJ was "the Budapest Declaration" which stated "the necessity of funding a World Federation of Science Journalists".

Still, I wanted István to view the meeting through the eyes of a prototypical young science reporter, akin to the one I met in Seoul. "Those young journalists (in Budapest) were in an optimistic historical moment", he wrote, being able to find "for the first time sitting in a roundtable the Editors in Chief of Nature, Science, La Recherche, New Scientist".

I missed the next WCSJ, in 2002 in Brazil. Fortunately, that was the first one for Jean-Marc Fleury, who has been by all means a privileged witness to their evolution ever since. Indeed, he would put together the next one, in Montreal, making it a watershed that would take these conferences in a completely different direction. I talked to him shortly after Seoul, and asked him about this transition:

"What I saw in Brazil (...) was an already planned meeting of academics who did research in science communication, to which had been tagged a few workshops and a few panels with some science journalists (...) I think very highly of science journalists and I wanted them to be in charge of their own profession. I didn't want academics or PR people to force science journalists", he told me.

Thus, Montreal made history not just because of its size - way beyond the pervious ones - but mainly because of its paradigm shifts. "There's a connection between many of the people who came to Montreal and what happened afterwards", said Fleury. "I think science journalists are still in control".

Let's assume they still are - did it show in Seoul?

For a few years now, the "academic" counterpart to WCSJ has been the biannual meeting of the Network on Public Communication of Science and Technology (PCST). It is true that a good portion of academics in last year's PCST meeting were absent from Seoul. Conversely, very many science journalists don't seem to find their way to PCST. Asked about it, Estrella Burgos, Editor of the Mexican science communication magazine ¿cómo ves?, was a bit ambivalent: "There were some proposals with an academic profile which were not accepted (for Seoul), assuming they might not be of much interest for practising science journalists", she explained to me. "But when we found academic proposals which we clearly saw would help journalists to do a better job, we approved them". She's talking about the Advisory Committee which helped put together the Program for Seoul, of which she was a member. In it, she told me, there was no tension between academics and practising journalists.

\footnotetext{
${ }^{3}$ Private communication, July 2015.
} 
It appears Jean-Marc Fleury is right: science journalists took over the WCSJ and have shaped it to their own benefit. So, what for, exactly?

I had a glimpse of a possible answer during one of the plenary sessions in Seoul. The title was irresistible - Data-jitsu: How to go (way) beyond Excel -, the delivery compelling and the contents inspiring. A couple of hours filled with teachable moments, I thought... and that's when it hit me: Back in 1999, in Budapest, I heard Joe Palca - of NPR fame - talk about the benefits of recognising teachable moments and incorporating them into the narrative of science journalism. I've been trying ever since, always revisiting Budapest in my mind. Years later, in Montreal, I sat in a session about power searches on the Internet and learnt a couple of techniques and tools, then new to me, which have been part of my craft ever since. The journalistic value of data mining, so grippingly presented as Data-jitsu in Seoul, fits the pattern perfectly: teachable moments in which the very many learn some powerul science journalism from some of our fellows.

Is this the meaning of "journalists in control" of WCSJ? Estrella Burgos was sympathetic: "To learn new tools, to practise certain ways of doing science journalism can help a lot, particularly in the present situation in which journalists must be extraordinarily versatile", she explained.

Jean-Marc Fleury advanced an even deeper idea when thinking about the youngsters in these meetings: "I want them to know that there is a community, bigger than they can imagine, and that it is international."

Then, he added, they can learn a few techniques, even admire a role model and wonder how they got to be who they are. But they need this sense of community, particularly in countries with very few science journalists around.

I did see this in Seoul, just as I had seen something similar in Budapest. Amongst the growing spurts of WCSJ, this may have been its eseence all along.

The $10^{\text {th }}$ WCSJ will take place in 2017, in San Francisco. The community is growing and it is still in control. Will it find itself shifitng paradigms once again?

Author

Javier Cruz-Mena. Physicist turned science journalist some 20 years ago. Combines reporting with teaching and scholarly research on science communication in mass media. Works at Mexico's National University (UNAM).

E-mail: cruzmena@dgdc.unam.mx.

\section{How to cite}

This article is licensed under the terms of the Creative Commons Attribution - NonCommercial NoDerivativeWorks 4.0 License.

ISSN 1824 - 2049. Published by SISSA Medialab. http:/ /jcom.sissa.it/.
Cruz-Mena J. (2015). 'World Conference of Science Journalists: what are they for?'. JCOM 14 (03), R02. 